\title{
Psikolojik Danışmanlık Alanında Mevcut ve Gelişen Etik Sorunlar*
}

\section{Current and Developing Ethical Problems in Psychological Counseling Field}

\author{
Ümüt ARSLAN**, Uğur Yiğit KARATAȘ***, Esma DOSTUOĞLU*****
}

Öz: Bu çalışmanın amacı psikolojik danışmanların psikolojik danışma ve rehberlik alanında yaşadıkları etik problemlerin ve ileride oluşabilecek etik problemlere dair öngörülerini incelemektir. Çalışmada veri toplamak amacıyla Delphi yöntemi kullanılmıştır. İlk turdan başlayarak, her tur sonrası değerlendirme yapılmıştır. Bu değerlendirme sonucunda bir sonraki turun soruları oluşturularak, toplam üç turda veriler toplanmıştır. Sosyal medya üzerinden psikolojik danışmanlık ve rehberlik sayfalarına duyurular yapılmış, gönüllü olan katılımcılara anketlerin linkleri elektronik posta (e-mail) yoluyla ulaştırılmış ve anketler Google form üzerinden uygulanmıştır. Toplam katılımcı sayısı 52 olup, katılımcıların $\% 62$ 'si kadın $\% 38$ 'i erkek olarak cinsiyetlerini belirtmişlerdir. Sonuçlar incelendiğinde psikolojik danışmanların günümüzde en çok problem olarak gördükleri temalar alan dışı atama, kısa süreli eğitimlerle ortaya çıkan unvan problemleri, çok kültürlü danışma, yetkinlik ve gizlilik olmuştur. Psikolojik danışmanların gelecekte karşılaşabileceklerini düşündükleri etik problem temaları ise kısa süreli eğitimlerle ortaya çıkan unvan problemleri, alan dışı atamalar, çok kültürlü danışma, yetkinlik, psikolojik danışmanlık mesleğinin branşlaşamaması ve etik kod karmaşası olarak ifade edilmiştir. Sonuçlar doğrultusunda, (a) alan dışı atamalar ve kısa süreli eğitim ile kullanılan unvanların psikolojik danışmanlık alanında yarattığı yetkinlik problemleri, (b) çok kültürlü danışma yeterlilikleri, (c) psikolojik danışmanlık mesleğinin tanımının ve ruh sağlığı yasasının önemi ve (d) uzun süredir revize edilmeyi bekleyen etik kodlar tartışılmıştır. Ayrıca, gizlilik konusunun psikolojik danışmanlıkta önemli bir etik ikilem konusu olmaya devam etmesi de bu çalışmada yerini almıştır.

Anahtar Kelimeler: Etik, psikolojik danışma ve rehberlik, Delphi, çok kültürlü danışma

\begin{abstract}
The aim of this study is to examine the current ethical problems and the ethical problems that may occur in the future in the psychological counseling and guidance field form psychological counselors' perspective. Delphi method was used to collect data. Starting from the first round, the evaluations were made after each round. As a result of these evaluations, the questions of the next round were formed and data were collected in three rounds in total. Announcements were made to the psychological counseling and guidance pages via social media. The links of the questionnaires to the volunteers were sent via e-mail, and the questionnaires were implemented via the Google form. The total number of participants was 52, and $62 \%$ of the participants stated their gender as female and $38 \%$ male. When the results were examined, it was seen that psychological counselors considered the most problematic problems currently are giving permission to non-counselors to work as counselors, title problems related to short-term training, multicultural counseling, competency, and confidentiality. Among the ethical problem themes that the psychological counselors think they may encounter in the future are title problems related to short-term training, giving permission to non-counselors to work as counselors, multicultural counseling, competency, the lack of the branch of the psychological counseling profession, and confusion of ethical codes. In the light of the results, (a) competency issues related to giving permission to work as counselors to noncounselors and using different titles after completing short-term training, (b) multicultural counseling competencies, (c) the importance of the psychological counseling profession description and the mental

\footnotetext{
* Bu çalışmanın bir kısmı 25-27 Ekim 2018 tarihinde 20. Uluslararası Psikolojik Danışmanlık ve Rehberlik Kongresi'nde sözlü bildiri olarak sunulmuştur.

** Sorumlu Yazar: Dr. Öğr. Üyesi, İzmir Demokrasi Üniversitesi, Eğitim Fakültesi, İzmir-Türkiye, ORCID: 00000002-3611-9607, e-posta: umut.arslan@idu.edu.tr.

*** Yüksek Lisans Öğrencisi, Pamukkale Üniversitesi, Eğitim Fakültesi, Denizli-Türkiye, ORCID: 0000-0003-41820331, e-posta: uguryigit20@gmail.com.

**** Psikolojik Danışman, ORCID: 0000-0003-0319-7526, e-posta: dstglesma01@ gmail.com.
} 
health law, and (d) expectation of the ethical codes revision that has been waited for a long time are discussed. In addition, this study has also taken place as the subject of confidentiality continues to be an important ethical dilemma in psychological counseling.

Keywords: Ethics, psychological counseling and guidance, Delphi, multicultural counseling

\section{Giriș}

Etik, insan davranışlarındaki doğru ve yanlış ayrımını, insan davranışlarının kabul görmüş kurallarını ve standartlarını içeren ahlak kavramıyla ilişkilidir (Jones, 2014). Etiğin amacı bütün taraflar için basit ahlak kurallarının ötesinde kabul gören bir yazılı formatta yüksek profesyonel standartlar oluşturmaktır (Hardal, 2011). Bir mesleğin uygulanması ile ilgili etik kurallar o meslek grubunun ortaya çıkmasının ardından oluşmaktadır. Bu etik kurallar insani değerler etrafinda şekillenmekte ve hizmet alanları için uygulamada güvenli çerçeveler sağlamaktadır (Oktay ve Oktay, 2018). Meslek grupları toplumlarda etik duyarlılığın artması ile birlikte mesleklerinin etik ilkelerini açıklama gereği duymuşlardır. Mesleklerin bağlı bulundukları kurum ve kuruluşlar ise, yayınladıkları ilkeler ile kendilerine bağlı üyelerin uygulamalarına standartlar getirerek ve onları denetleyerek mesleklerini korumayı amaçlamaktadırlar (Taşdan ve Yalçın, 2007). Meslek üyelerinin bağlı bulundukları dernekler, denetleme ve standart oluşturma kapsamında etik ilkeler ile ilişkili etik kodları oluştururlar.

Etik kodlar etik ilkeler çerçevesinde oluşturulur. Bu kodlar meslek elemanlarının yeterliliklerini ve etik davranışlarını tanımlayarak, alan çalışanlarına rehberlik etmektedir. Etik kodların amacı bu alanda çalışan kişilerin karşılaşabilecekleri olası sorunlarda onlara yardımcı olabilmektir. Bu kurallar ayrıca gereken durumlarda idari ve adli makamların verecekleri kararlarda başvuru kaynağı olarak kullanılır (Türk Psikolojik Danışma ve Rehberlik Derneği [TPDRD], 2012).

Psikolojik danışmanlık alanında ise etik, mesleki uygulama için kabul görmüş uluslararası yerleşik standartları ortaya koymaktadır (Jones, 2014). Bu standardı korumak için etik kodlar oluşturulmaktadır. Her mesleğin çeşitli etik ilkeleri ve kodları olmakla birlikte, psikolojik danışmanlık ve rehberlik gibi doğrudan insana hizmet eden mesleklerde, insan doğasının karmaşık yapısıyla bağlantılı olarak, meslek odası ya da meslek örgütleri tarafından oluşturulan ilke ve kodları zorlayan ya da esneten durumlar bulunmaktadır (Camadan, 2018). Dolayısıyla, uluslararası standartlarda psikolojik danışmanlık, daha önce belirlenmiş olan etik kodları periyodik olarak güncelleyerek mesleğin profesyonel statüsünü korumaktadır (Amerikan Danışmanlık Derneği [ACA], 2014; Amerikan Okul Danışmanları Birliği [ASCA], 2010; İngiliz Danışmanlık ve Psikoterapi Derneği [BACP], 2018). Etik kodlar oluşturulduktan sonra teknolojik, sosyal ve kültürel gelişmelere paralel olarak, bu kodların periyodik biçimde revize edilmesi gerektiğinden, etik kod oluşturma süreci devam eden ve gelişen bir süreçtir (Çetinkaya, 2014). Bu durum psikolojik danışmanlarda bir güncellenme ihtiyacını da ortaya çıkarmaktadır (Herlihy ve Dufrene, 2011). Etik, psikolojik danışma sürecinin her aşamasında psikolojik danışmanın içselleştirmesi gereken önemli bir gereklilik ve yön gösterici bir pusula olduğu için (Akfert, 2012), psikolojik danışmanlık programlarında etik ilkeler açısından bir bilinçlilik sağlanması (Oktay ve Oktay, 2018) ve psikolojik danışmanlık öğrencilerinin yetkinliğinin yeterli düzeye çıkarılması önemlidir.

Türk PDR Derneği tarafından, ülkemizdeki psikolojik danışma ve rehberlik hizmetleri için yayınlanan ilke ve kodların oluşturulmasında, ABD'deki psikolojik danışmanlık derneklerinin (ACA ve ASCA) etik yaklaşım ve kodları örnek alınmıştır (Arslan ve SommersFlanagan, 2018a; İkiz, Sevinç, Kaval, Yeğintürk ve Kalen, 2017b).

Türkiye'de psikolojik danışmanlar için etik kodlar ilk olarak, kuruluşundan 6 yıl sonra Türk PDR Derneği (1995) tarafından tanıtılmış ve bu kodların revize edilmiş versiyonu (2006) hala kullanımdadır. Hem kodların geliştirilmesi hem de revizyonu, bir görev gücünün üzerinde çalıştığı ve görevi tamamladıktan sonra danışmanları kamuya açık hale getirdiği bir masa yaklaşımıyla gerçekleştirilmiştir. ACA (2014) ve Türk PDR Derneği (2006) etik kodlarının karşılaştırması, Türk PDR Derneği etik kodlarının oldukça sınırlı bir kapsamda ve ayrıntılandırılmamış olduğunu göstermektedir. Türk PDR Derneği etik kodları üç ana kategoride 
sunmaktadır: Temel Kavramlar, Temel İlkeler ve Etik Standartlar. İlk kategori psikolojik danışmanlığın diğer ruh sağlığı mesleklerinden farklılıklarını ve psikolojik danışmada profesyonel etiğin gerekliliğinin nedenlerini belirtmekte; ikinci kategori ise dürüstlük, mesleki yeterlilik, çok kültürlü duyarlılık, etik ilkeler ve mesleki sorumluluklar gibi kavramların bir özetini sunmakta; üçüncü kategori etik standartlardan (etkinlik sınırları, başkalarına zarar vermeme, gizlilik, ücret, bireysel farklılıklar, başkalarına saygı) oluşmaktadır. Son derece ayrıntılı ACA (2014) etik kodlarının (dokuz kategori, 67 başlık ve 249 madde) aksine, Türk PDR Derneği (2006) kodları sekiz genel kategoride (genel standartlar, psikolojik danışmanlık ilkeleri, değerlendirme, araştırma ve yayın, psikolojik danışma, psikolojik danışmanlık eğitimi, özel uygulama ve personel yönetimi) listelenen 101 madde içerir.

\section{Psikolojik danışmada karşılaşılan etik problemler}

Türkiye'de, psikolojik danışmanlık alanında yapılan araştırmalara bakıldığında etik konusundaki yapılan çalışmaların kısıtlı olduğu görülmektedir. Literatür incelendiğinde, etik alanında daha çok gizlilik (Akfert, 2012; Çetinkaya, 2014; 2015; Herlihy ve Dufrene, 2011; İkiz ve diğerleri, 2017b; İkiz, Şensoy, Balkan ve Akıman, 2017c; İkiz, Otlu, Arslan, 2017a; Lehr, Lehr ve Sumarah, 2007; Yam, 2017), ikili ilişkiler (Hardal, 2011; İkiz ve diğerleri, 2017c; Arslan ve Sommers-Flanagan, 2018a) ve yetkinlik (Arslan ve Sommers-Flanagan, 2018b; Camadan, 2018; Lehr ve diğerleri, 2007) konularında çalışmalar olduğu görülmektedir.

\section{Gizlilik}

Literatürde yapılan çalışmalara bakıldığında psikolojik danışmanların etik açısından özellikle gizlilik konusunda sorun yaşadıkları belirtilmektedir (Akfert, 2012; Çetinkaya, 2014; 2015; Herlihy ve Dufrene, 2011; İkiz ve diğerleri, 2017a; 2017b; 2017c; Lehr ve diğerleri, 2007; Yam, 2017). Gizlilik ilkesi psikolojik danışma sürecinin bütün evrelerinde, danışanın psikolojik danışmana karşı güven duymasına katkı sağlayan önemli bir öğesidir. Aynı zamanda, bazı durumlarda temel ilkeler ile çeliştiği için katı bir şekilde sürdürülemeyeceği de göz önünde bulundurulmalıdır (Camadan, 2018). Özellikle danışanın kendisine veya başkasına zarar verme ihtimalinin olduğu durumlarda, gizlilik ilkesinin uygulanmaması zorunluluğu vardır. Ancak, Türkiye'de psikolojik danışmanların kendisine veya başkasına zarar verebilecek bir danışan karşısında nasıl bir yol izlemeleri gerektiği konusunda bilgileri sınırlıdır (Arslan ve SommersFlanagan, 2018a). Ayrıca, öğrencileri mahremiyet konularında bilgilendirmek; danışanların bilgilerini öğretmenler, veliler ve başkaları ile paylaşmak; öğrencilere bilgilendirilmiş onay formu imzalatmak; mesleki gizliliği korumak; okul personeline (öğretmen, idari personel) karş1 danışmanın gizliliğini korumak okul psikolojik danışmalarının sorun olarak gördükleri konuların başında gelmektedir (Lehr ve diğerleri, 2007). Buna ek olarak psikolojik danışmanların gizlilik ile ilgili davranışlarda en çok kaygı ve kararsızlık duygusu yaşadıkları ortaya çıkmıştır (Yam, 2017). Temel olarak gizlilik ilkesi psikolojik danışmanlıkta en çok ikilem yaşanan ilke olarak görülmektedir (Akfert, 2012; Çetinkaya, 2014; 2015; Herlihy ve Dufrene, 2011; İkiz ve diğerleri, 2017a; Lehr ve diğerleri, 2007; Yam, 2017).

\section{Yetkinlik}

Psikolojik danışma hizmeti profesyonel olarak verilmesi gereken bir hizmettir. Profesyonellik göz önünde bulundurulduğunda bu hizmeti veren kişilerin çalışmalarında objektif, bilimsel ve sistemli olmaları önemlidir. Bu açıdan bakıldığında yardım hizmetini veren kişilerin alanlarında yetkin olmaları gerekmektedir (Camadan, 2018). Yapılan çalışmalarda yetkin olmayan kişilerin okul psikolojik danışmanı olarak çalışmaları önemli bir etik sorun olarak görülmektedir (Akfert, 2012; Arslan ve Sommers-Flanagan, 2018b; Camadan, 2018; Hardal, 2011; İkiz ve diğerleri 2017b; Lehr ve diğerleri, 2007). Psikolojik danışmanlarla yapılan bir başka çalışmada ise psikolojik danışmanların mesleki yeterliliği önemli gördükleri ortaya konulmuştur (İkiz ve diğerleri, 2017b).

Arslan ve Sommers-Flanagan'in (2018a) çalışmasında ise psikolojik danışman adaylarının psikolojik danışma sürecinin yürütülemeyeceği durumlarda, yüksek farkındalık sahibi iken yetkin olmadıkları alanlarda psikolojik danışma yapılmaması gerektiği konusunda 
farkındalıklarının düşük olduğu belirtilmektedir. Yine okul psikolojik danışmanları ile yapılan bir çalışmada ise okul psikolojik danışmanlarının çalışmalarına eğitim yöneticilerinin müdahale etmeleri, yetkin olmadıkları konularda çalışmak zorunda kalmaları, yetkin olmayan kişilerin okul psikolojik danışmanı olarak çalışıyor olması, farklı kültürdeki danışanlarla bir arada olunması ve okul psikolojik danışmanının bu konuda yetkin olmaması ve gizlilik ihlalleri durumunda yaşanılan sorunları etik sorunlar olarak gördükleri belirtilmiştir (İkiz ve diğerleri, 2017b).

\section{İkili ilişkiler}

Psikolojik danışma sürecinde ikili ilişkiler, danışmanların içinde oldukları ya da böyle bir ilişki içine girmeyi düşündükleri veya danışanlarla içinde bulundukları ilişki çeşitleridir (Jones, 2014). Bu ilişki çeşitleri arkadaş, sevgili, meslektaş, eğitimci veya gözlemci olabilir. Danışanla psikolojik danışman arasındaki ikili ilişkinin etik dışı olup olmadığı bu ilişkinin şartlarına bağlıdır. Jones'e (2013) göre ikili ilişkilerin etik ihlal sonucu istismara yol açtığı durumlar psikolojik danışmanın (a) danışan ile cinsel yakınlık içeren ilişkiye girmesi, (b) kişisel gündemi için danışanı kullanması, (c) danışma sürecinde öncelikli olarak ekonomik çıkar gözetmesi ve (d) danışanı duygusal olarak istismar etmesidir. Hardal'ın (2011) çalışmasına göre ruh sağlığı profesyonellerinin ikili ilişki ihlalinde daha az duyarlı davrandıkları ve ikili ilişkilerle ilgili ihlalleri sıklıkla rapor ettikleri belirtilmektedir. İkiz ve diğerleri (2017c) ile Arslan ve SommersFlanagan'in (2018a) çalışmalarında, psikolojik danışmanlar cinsel olmayan ikili ilişkileri, cinsel olan ikili ilişkilere oranla etik açıdan daha kabul edilebilir görmektedirler.

Psikolojik danışmanların genel olarak yetkinlik, gönüllülük, gizlilik ve ikili ilişkiler konularında etik sorun ve ikilemler yaşadıkları söylenebilir (Camadan, 2018). Ergene'nin (2004) çalışmasına göre ülkemizde psikolojik danışmanlık ve rehberlikte etik konusunda yapılan araştırma ve yayınlarda ciddi sıkıntılar olduğu belirtmiştir. Yam'ın (2017) çalışmasına göre, etik ikilem konusunda Türkiye'deki alan yazınında az sayıda araştırmaya rastlanıldığı belirtilmektedir. Bunun yanı sıra ülkemizde lisans düzeyi eğitimde, yalnızca iki kredilik meslek etiği ve yasal konular dersi alınması da yine yetkinlik açısından bir sorun olarak görülebilir. Nitekim İkiz ve diğerleri (2017a) çalışması etik eğitimine yoğunluk ve önem vermek için, bu konuda lisans eğitimine öncelik duyulduğunu göstermektedir. Yine bu bağlamda Arslan ve Sommers-Flanagan'in (2018a) çalışmasında psikolojik danışman adaylarının etik bilgisinin kaynă̆ını, büyük oranda danışmanlık programı olarak gördükleri belirtilmektedir. Lisans düzeyindeki bu az sayıdaki ders Hardal'ın (2011) çalışmasında da bir eksiklik olarak görülmektedir. Bu bağlamda üniversitelerde verilen meslek etiği derslerinin güncel yasa ve çalışma koşulları ile uyumlu olması ve buna yönelik olarak Milli Eğitime bağlı okullarda hizmet içi eğitimlerin sürekliliğinin sağlanması önerilmektedir (İkiz ve diğerleri, 2017c).

Psikolojik danışmada etik, dinamik ve değişen bir süreçtir. $\mathrm{Bu}$ yüzden psikolojik danışmanlık eğitimi verenler, etik karar verme süreçlerinin nasıl işlediğini ve hangi etik karar verme modellerinin etkili olduğunu keşfetmeye devam etmelidirler. Bu sürecin devam edebilmesi için, günümüzde karşılaşılan ve gelecekte karşılaşılması muhtemel etik problemler üzerine çalışmaların aralıksız devam etmesi gerekmektedir.

$\mathrm{Bu}$ çalışmanın iki temel amacı vardır. Birincisi psikolojik danışmanların günümüzde yaşadığı etik problemleri belirlemeye çalışmaktır. İkincisi ise psikolojik danışmanların gelecekte karşılaşılabilecek etik problemlere dair kendi öngörülerini belirlemektir.

\section{Yöntem}

Skulmoski, Hartman ve Krahn (2007) Delphi çalışmasını 11 aşamadan oluşturduklarını belirtmişlerdir. Bu çalışmanın prosedüründe Skulmoski ve diğerlerinin (2007) yaklaşımı temel alınmıştır.

\section{Araştırma sorusunun geliştirilmesi}

$\mathrm{Bu}$ çalışmanın ilk aşaması psikolojik danışmanlık alanında günümüzdeki ve gelecekteki etik problemlerin tespitine yönelik araştırma ihtiyacının fark edilmesidir. Bunun üzerine yapılan literatür taramasında Herlihy ve Dufrene'nin (2011) psikolojik danışmanlık alanında etik 
problemleri tartıştı̆̆ makalesindeki araştırma problemleri dikkat çekmiştir. Herlihy ve Dufrene (2011) çalışmalarında psikolojik danışmanlık alanında Amerika Birleşik Devletleri'nde yaşanan ve gelecekte yaşanması öngörülen etik problemleri tartışmışlardır. Bu çalışmanın benzerinin Türkiye' deki psikolojik danışmanlık alanındaki etik problemleri tartışmak için yapılmasının alana katk1 sağlanacağ1 düşünülmüştür. Bu nedenle "Türkiye'deki psikolojik danışmanlar için günümüzde yaşanan ve gelecekte yaşanması öngörülen önemli etik problemler nelerdir?” sorusu, bu çalışmanın cevabını aradığı husus olarak belirlenmiştir.

\section{Araştırmanın dizaynı}

$\mathrm{Bu}$ araştırma Delphi yöntemiyle yapılmıştır. Delphi yöntemi, uzmanların görüşlerini sıralı bir anket dizini ile tekrarlı geri bildirimle toplayan ve değerlendiren bir süreçtir (Skulmoski ve diğerleri, 2007). İlkinden başlanarak uygulanan anketlerin değerlendirilmesi ile bir sonraki anketin soruları geliştirilir. Delphi yönteminin temel özellikleri katılımcıların anonim olması (katılımcılar üzerindeki sosyal baskıyı uzaklaştırmak), tekrarlama (katılımcıların görüşlerini gözden geçirmelerine ve şekillendirmelerine yardımcı olmak), kontrollü geri bildirim (katılımcıları birbirlerinin görüşleri hakkında bilgilendirip, onların görüşlerini netleştirmelerine yardımcı olmak) ve grup yanıtlarının istatistiksel olarak hesaplanmasıdır (sonuçları toplamak ve yorumlamak; Rowe ve Wright, 1999).

\section{Araştırmanın örneklemi}

Delphi çalışmalarında katılımcı grubu, yapılan çalışma hakkında belirli bir derecede bilgiye sahip olmalıdır. Bu çalışmanın amacı psikolojik danışmanlık alanında var olan ve gelecek yıllarda ortaya çıkması muhtemel etik problemleri gözlemlemek olduğu için, katılımcıların psikolojik danışman olarak aktif bir şekilde görev yapıyor olması ve belli bir süre deneyimli olması bu çalışma için önemli bir faktördür. Bu nedenle çalışmanın katılımcıları, psikolojik danışmanlık alanında en az beş yıl deneyime sahip olan psikolojik danışmanlar arasından belirlenmiştir. Anket, katılımcılara Google form üzerinden uygulanmış ve böylelikle katılımcıların gizliliği ve gönüllülüğü sağlanırken, geleneksel iletişim yöntemlerinden kaynaklanan gecikmeler yaşanmamıştır. Sosyal medya üzerinden psikolojik danışmanlık ve rehberlik sayfalarına duyurular yapılmıştır. Kendisini araştırmanın katılım koşullarını karşıladığını belirten gönüllü olan katılımcılara anketlerin linkleri elektronik posta (e-mail) yoluyla ulaştırılmıştır.

\section{Delphi çalışması için birinci anketin geliş̧irilmesi}

Anket, bu aşamada katılımcıların özgürce cevap verebilecekleri bir formda düzenlenmeye çalış1lmıştır. Günümüzde ve gelecekte öngörülen olası etik problemler için iki adet açık uçlu soru sorulmuş, katılımcıların kendi fikirlerini yazmaları hedeflenmiştir.

\section{Delphi pilot çalışması}

Karar verilen soruların oluşum sürecinde, psikolojik danışmanlık ve rehberlik alanındaki öğretim üyeleri ve yüksek lisans öğrencileri ile görüşülmüştür. Ayrıca soruların anlaşılabilirliği hususu ve ortaya çıkabilecek diğer olası problemler tartışılarak anket sorularına son hali verilmiştir.

- Günümüzde psikolojik danışmanlık alanında karşılaşılan en önemli etik sorunların neler olduğunu düşünüyorsunuz? En az üç tane yazınız.

- Önümüzdeki beş yıl içerisinde psikolojik danışmanlık alanında hangi etik sorunların ortaya çıkacağını düşünüyorsunuz? En az üç tane yazınız

\section{Anketin birinci turunun sonuçlarının toplanması ve açıklanması}

Birinci turda alınan yanıtlar kategorize edilmiş ve ilk turun sonuçlarına ulaşılmıştır. Bu kategorileştirme, verilen cevapların kodlanması üzerinden yapılmıştır. Birinci turun sonuçlarında günümüzdeki etik problem için 14 kategori (Tablo 1) ve gelecekteki etik problemler için 17 kategori (Tablo 2) ortaya çıkmıştır. 


\section{İkinci tur için anketin geliştirilmesi}

İlk turdaki açık uçlu soruların cevapları doğrultusunda oluşturulan kategoriler, ikinci turda derecelendirilmek üzere seçmeli sorular şeklinde (52 katılımcıya) sorulmuştur. Bunun yapılmasındaki amaç, etik problemlerin en çok tercih edilenlerini ortaya koymak adına hangi etik problemlerin daha çok katılımcı açısından önemli ifade edildiğini ve istisna (az tercih edilen) etik problemlerin neler olarak ifade edildiğini belirlemektir. Aşağıdaki sorular sorularak katılımcılardan en önemlileri seçmeleri istenmiştir.

- Günümüzde psikolojik danışmanlık alanında karşılaşılan en önemli etik sorunların neler olduğunu düşünüyorsunuz? Üç seçeneği işaretleyiniz.

- Önümüzdeki beş yıl içerisinde psikolojik danışmanlık alanında hangi etik sorunların ortaya çıkacağını düşünüyorsunuz? Üç seçeneği işaretleyiniz.

\section{Anketin ikinci turunun sonuçlarının toplanması ve açıklanması}

İkinci turda katılımcıların verdiği cevaplar doğrultusunda en çok ve en az tercih edilen kategoriler belirlenmiştir.

\section{Üçüncü tur için anketin geliştirilmesi}

Çok tercih edilen anket sorularının biraz daha belirginleştirilip sorulması ve az tercih edilen anket sorularının anketten çıkartılması ile oluşturulan formda, katılımcılardan kategorilerdeki etik sorunları derecelendirmeleri istenmiştir. Bu kapsamda günümüzdeki etik problemler ile ilgili 12 kategori ve gelecekteki olası etik problemler ile ilgili 13 kategori belirlenmiştir. Sorular 1'den 4'e kadar derecelendirmeli Likert tipi anket şeklinde katılımcılara sunulmuştur. Puanlama sisteminde 1. Derecede Önemli için 4, 2. Derecede Önemli için 3, 3. Derecede Önemli için 2 ve 4. Derecede Önemli için 1 puan verilmiştir.

- Günümüzde psikolojik danışmanlık alanında yaşanan ve aşağıda listelenen etik sorunlarının sizin deneyimlerinize göre hangi derece önemli olduğunu işaretleyiniz.

- Önümüzdeki beş yıl içerisinde, psikolojik danışmanlık alanında yaşanabilecek ve aşağıda listelenen etik sorunların sizin deneyimlerinize göre hangi derece önemli olduğunu işaretleyiniz.

Anketin üçüncü turunun sonuçlarının toplanması ve açıklanması

Anketlerde verilen cevapların kategorilere göre aritmetik ortalamaları hesaplanmış ve analizleri yapılmıştır.

\section{Araştırma Sonuçlarını Doğrulama, Genelleştirme ve Raporlaştırma}

Araştırma sonuçlarının tekrar kontrol edilmesi ve literatür ile karşılaştırılması sonrasında ve sonuçlar raporlaştırılmıştır.

\section{Sonuçlar}

Toplamda 52 katılımcı tarafindan üç turdaki anket sorularına verilen cevaplar toplanmış ve analiz edilmiştir. Katılımcıların hepsi en az beş yıldır psikolojik danışman olarak görev yapmaktadırlar. Katılımcıların 32'si kadın (\%62) ve 20'si (\%38) erkek olarak cinsiyetlerini belirtmişlerdir.

\section{Günümüzdeki etik sorunlar}

Psikolojik danışmanların günümüzde karşılaştıkları etik problemleri tespit etmek için üç tur anket düzenlenmiştir. Birbirinin devamı niteliğindeki aşağıdaki sorular sırasıyla üç turda sorulmuştur.

1. Tur: Günümüzde psikolojik danışmanlık alanında, karşılaşılan en önemli etik sorunların neler olduğunu düşünüyorsunuz? En az üç tane yazınız.

2. Tur: Günümüzde psikolojik danışmanlık alanında, karşılaşılan en önemli etik sorunların neler olduğunu düşünüyorsunuz? Üç seçeneği işaretleyiniz.

3. Tur: Günümüzde psikolojik danışmanlık alanında yaşanan ve aşağıda listelenen etik sorunlarının sizin deneyimlerinize göre hangi derece önemli olduğunu işaretleyiniz. 
İlk turda sorulan açık uçlu soruların cevapları incelendiğinde, katılımcıların günümüzde karşılaşılan etik sorunların neler olduğuna dair verdikleri cevaplarla 14 kategori ortaya çıartılmıştır (Tablo 1). İkinci turda ise katılımcılardan ilk turdaki sonuçlar doğrultusunda oluşturulan kategorilerden en önemli etik problem olarak gördükleri üç tanesini seçmeleri istenmiştir. Katılımcılar 14 kategoriden 11 tanesini en az bir kere seçmişlerdir. Geriye kalan üç kategori ise ikinci turda hiç seçilmemiştir (Madde A12, A13 ve A14). Alan dışı atamalar (Madde A3, n=56), kısa süreli eğitimlerle ortaya çıkan unvan problemleri (Madde A9, n=49), çok kültürlü psikolojik danışma (Madde A5, $n=19$ ) ve yetkinlik (Madde A4, n=15) ikinci turda kategoriler arasında en çok işaretlenen maddeler olmuştur.

Son olarak üçüncü turda, ikinci turda en az bir kere işaretlenen 11 kategori için Likert tipi anket yapılmıştır. Likert tipi anket ile katılımcılardan günümüzdeki etik problemlerin önem derecesini belirtmeleri istenmiştir (1. derece, 2. derece, 3. derece ve 4. derece). Bu kapsamda maddelerin aritmetik ortalamaları hesaplanmıştır. En fazla ortalamaya sahip olan ilk beş madde gizlilik (Madde A1, $\bar{x}=3,58$; Madde A2, $\bar{x}=3,52$ ), alan d1ş1 atamalar (Madde A3, $\bar{x}=3,48$ ), yetkinlik (Madde A4; $\overline{\mathrm{x}}=3,46)$ ve çok kültürlü psikolojik danışmanlık (A5; $\overline{\mathrm{x}}=3,44)$ olmuştur.

\section{Gelecekteki etik sorunlar}

Psikolojik danışmanların gelecekte karşılaşabilecekleri etik problemleri tespit etmek için üç tur anket düzenlenmiştir. Birbirinin devamı niteliğindeki aşağıda yer alan sorular sırasıyla üç turda sorulmuştur.

1. Tur: Önümüzdeki beş yıl içerisinde psikolojik danışmanlık alanında hangi etik sorunların ortaya çıkacağını düşünüyorsunuz? En az üç tane yazınız

2. Tur: Önümüzdeki beş yıl içerisinde psikolojik danışmanlık alanında hangi etik sorunların ortaya çıkacağını düşünüyorsunuz? Üç seçeneği işaretleyiniz.

3. Tur: Önümüzdeki beş yıl içerisinde, psikolojik danışmanlık alanında yaşanabilecek ve aşağıda listelenen etik sorunların sizin deneyimlerinize göre hangi derece önemli olduğunu işaretleyiniz.

İlk turda sorulan, gelecekteki olası etik sorunlara ilişkin açık uçlu sorulara, katılımcıların verdikleri cevaplar sonucunda 17 kategori ortaya çıkarılmıştır (Tablo 2). İkinci turda ise katılımcılardan ilk turdaki sonuçlar doğrultusunda oluşturulan kategorilerden en önemli etik problem olarak gördükleri üç tanesini seçmeleri istenmiştir. Katılımcılar 17 kategoriden 13 tanesini toplamda en az bir kere işaretlemiştir. Geriye kalan dört kategori ise hiç işaretlenmemiştir. Kısa süreli eğitimlerle ortaya çıkan unvan problemleri (Madde B8, n=38), alan dış1 atamalar (Madde B2, n=37) ve çok kültürlü psikolojik danışmanlık (B3, n=23) ikinci turda kategoriler arasında en çok işaretlenen maddeler olmuştur.

Son olarak üçüncü turda, ikinci turda en az bir kere işaretlenen 13 kategori için Likert tipi anket uygulanmıştır. Likert tipi anket ile katılımcılardan gelecekte yaşanabilecek etik problemlerin önem derecesini belirtmeleri istenmiştir (1. derece, 2. derece, 3. derece ve 4. derece). $\mathrm{Bu}$ kapsamda maddelerin aritmetik ortalamaları hesaplanmıştır. En fazla ortalamaya sahip olan ilk beş kategorideki maddeler sırası ile yetkinlik (Madde B1, $\bar{x}=3,56$ ), alan dış1 atamalar (Madde $\mathrm{B} 2, \overline{\mathrm{x}}=3,52$ ), çok kültürlü psikolojik danışmanlık (Madde B3; $\overline{\mathrm{x}}=3,42$ ), psikolojik danışmanlık mesleğinin branşlaşamaması (Madde $\mathrm{B} 4 ; \overline{\mathrm{x}}=3,32$ ) ve etik kod karmaşası (Madde $\mathrm{B} 5$; $\overline{\mathrm{x}}=3,30$ ) olmuştur. 
Tablo 1.

Günümüzdeki Etik Sorunlar: 1., 2. ve 3. Tur Sonuçları

\begin{tabular}{|c|c|c|c|c|c|c|c|}
\hline 1. Tur Sonuçlarına Göre Günümüzdeki Sorun Temaları & 2. Tur & $\overline{\mathrm{x}}^{* *}$ & 1. & $\begin{array}{l}\text { Ön } \\
\text { Dere } \\
(\%)\end{array}$ & $\begin{array}{l}\text { em } \\
\text { ecesi } \\
* * *\end{array}$ & 4. & 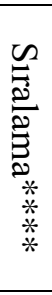 \\
\hline $\begin{array}{l}\text { A1- Psikolojik danışmanların gizlilik ilkesini } \\
\text { bilmemelerinden kaynaklanan etik problemler }\end{array}$ & 8 & 3,6 & 84 & 2 & 2 & 12 & 1 \\
\hline $\begin{array}{l}\text { A2- Psikolojik danışmanların gizlilik ilkesini bildiği } \\
\text { halde başka bir nedenden dolayı (kişisel çıar, ihmal, } \\
\text { dikkat eksikliği) gizlilik ilkesini ihmal etmeleri. } \\
\text { A3- Sosyoloji, felsefe, eğitim bilimleri, psikoloji gibi }\end{array}$ & 5 & 3,5 & 80 & 2 & 8 & 10 & 2 \\
\hline $\begin{array}{l}\text { lisans programlarından mezun olanların pedagojik } \\
\text { formasyon alıp rehber öğretmen unvanı kullanmaları. }\end{array}$ & 56 & 3,5 & 74 & 12 & 2 & 12 & 3 \\
\hline $\begin{array}{l}\text { A4- Psikolojik danışmanların yetkinliğindeki } \\
\text { eksikliklerden kaynaklanan etik problemler }\end{array}$ & 15 & 3,5 & 70 & 16 & 4 & 10 & 4 \\
\hline $\begin{array}{l}\text { A5- Psikolojik danışmanların ön yargılarından dolayı } \\
\text { farklılıklara saygı duymaması. }\end{array}$ & 19 & 3,4 & 72 & 12 & 4 & 12 & 5 \\
\hline $\begin{array}{l}\text { A6- Psikolojik danışmanların cinsel taciz ve istismar } \\
\text { vakalarında çekimser bir tutum sergilemeleri. }\end{array}$ & 9 & 3,4 & 66 & 18 & 4 & 12 & \\
\hline $\begin{array}{l}\text { A7- Psikolojik danışmanların mesleki çerçeve ve } \\
\text { unvanları ile ilgili sorunlarının uygulamada yarattığı etik } \\
\text { problemler }\end{array}$ & 14 & 3,2 & 50 & 28 & 14 & 8 & \\
\hline $\begin{array}{l}\text { A8- Psikolojik danışmanların çalıştıkları kurumlarda } \\
\text { alanları ile ilgili olmayan işler yapmaları (evrak işleri } \\
\text { vs.). }\end{array}$ & 10 & 3,1 & 46 & 32 & 10 & 12 & \\
\hline $\begin{array}{l}\text { A9- Herhangi bir kurumdan kısa süreli eğitim ile } \\
\text { uygulama sertifikası alarak psikoterapist unvanı kullanan } \\
\text { psikolojik danışmanlar. }\end{array}$ & 49 & 3,1 & 52 & 18 & 16 & 14 & \\
\hline $\begin{array}{l}\text { 10- Psikolojik danışmanların bilimsel verileri kullanmak } \\
\text { yerine sektörel yönelimlere başvurmaları. }\end{array}$ & 9 & 2,9 & 36 & 32 & 22 & 10 & \\
\hline $\begin{array}{l}\text { A11- Psikolojik Danışmanlık ve Rehberlik lisans } \\
\text { programlarından mezunlarının özel üniversitelerde klinik } \\
\text { psikoloji yüksek lisans programını bitirdikten sonra } \\
\text { "Klinik Psikolog" unvanını kullanmaları. }\end{array}$ & 7 & 2,3 & 14 & 30 & 24 & 32 & \\
\hline $\begin{array}{l}\text { A12- Psikolojik danışmanların kişisel çıkarlarını } \\
\text { danışanlarının çıkarlarının önünde tutmaları. }\end{array}$ & 0 & - & - & - & - & - & \\
\hline $\begin{array}{l}\text { A13- Psikolojik danışmanların danışanları ile kurdukları } \\
\text { cinsel olmayan ikili ilişkiler. }\end{array}$ & 0 & - & - & - & - & - & \\
\hline $\begin{array}{l}\text { A14- Psikolojik danışmanların danışanları ile kurdukları } \\
\text { cinsel ikili ilişkiler. }\end{array}$ & 0 & - & - & - & - & - & \\
\hline
\end{tabular}

Açıklama: * 2. turda katılımcılar tarafından toplam işaretlenme sayısı, ** 3. turda katılımcıların cevaplarının Likert ölçeğine göre (1. Derecenden önemli 4 puan, 4. Derecede önemli 1 puan) aritmetik ortalaması, ***3. turda katılımcıların cevaplarının önem derecesine göre yüzdeleri, $* * * * 3$. tur sonuçlarına göre (aritmetik ortalama) ilk 5'te yer alan temaların sıralaması. 
Tablo 2.

Gelecekteki Etik Sorunlar: 1., 2. ve 3. Tur Sonuçları

\begin{tabular}{|c|c|c|c|c|c|c|c|}
\hline \multirow[t]{2}{*}{ 1. Tur Sonuçlarına Göre Gelecekteki Sorun Temaları } & \multirow[t]{2}{*}{$\begin{array}{l}\text { 2. Tur } \\
\text { n* }\end{array}$} & \multicolumn{6}{|c|}{$\begin{array}{l}\text { 3. Tur } \\
\text { Önem Derecesi } \\
(\%)^{* * *}\end{array}$} \\
\hline & & & 1. & 2. & 3. & 4. & \\
\hline B1- Psikolojik danışmanların yetkinliği. & 15 & 3,6 & 78 & 10 & 2 & 10 & 1 \\
\hline B2- Sosyoloji, felsefe, eğitim bilimleri, psikoloji gibi & & & & & & & \\
\hline $\begin{array}{l}\text { lisans programlarından mezun olanların pedagojik } \\
\text { formasyon alıp rehber öğretmen unvanı kullanmaları. }\end{array}$ & 37 & 3,5 & 80 & 6 & 0 & 14 & 2 \\
\hline $\begin{array}{l}\text { B3- Psikolojik danışmanların ön yargılarından dolayı } \\
\text { farklılıklara sayg1 duymaması. }\end{array}$ & 23 & 3,4 & 68 & 14 & 10 & 8 & 3 \\
\hline $\begin{array}{l}\text { B4- Psikolojik danışmanlık ve rehberlik alanındaki } \\
\text { branşlaşamama sorunu. }\end{array}$ & 15 & 3,3 & 62 & 18 & 10 & 10 & 4 \\
\hline $\begin{array}{l}\text { B5- Bilgi kirliliğinin artmasından doğan etik kod } \\
\text { karmaşası. }\end{array}$ & 18 & 3,3 & 56 & 28 & 6 & 10 & 5 \\
\hline $\begin{array}{l}\text { B6- Psikolojik danışman ile danışan arasındaki ilişkide } \\
\text { terapötik koşulların sağlanamaması. }\end{array}$ & 5 & 3,2 & 48 & 36 & 8 & 8 & \\
\hline $\begin{array}{l}\text { B7- Psikolojik danışmanlık alanındaki etik kodların } \\
\text { güncel gelişmelere göre yenilenmemesi. }\end{array}$ & 10 & 3,2 & 50 & 28 & 14 & 8 & \\
\hline $\begin{array}{l}\text { B8- Herhangi bir kurumdan kısa süreli eğitim ile } \\
\text { uygulama sertifikası alarak psikoterapist unvanı } \\
\text { kullanan psikoloiik danısmanlar. }\end{array}$ & 38 & 3,1 & 50 & 28 & 8 & 14 & \\
\hline $\begin{array}{l}\text { B9- Psikolojik danışmanların yaşadıkları ekonomik } \\
\text { sıkıntılardan doğan etik kaygılar. }\end{array}$ & 4 & 3 & 30 & 50 & 14 & 6 & \\
\hline $\begin{array}{l}\text { B10- Psikolojik danışmanların ücret ile ilgili yaşadıkları } \\
\text { sorunlar. }\end{array}$ & 4 & 2,8 & 18 & 48 & 28 & 6 & \\
\hline $\begin{array}{l}\text { B11- Psikolojik danışmanların sosyal medyadaki ikili } \\
\text { ilişkileri. }\end{array}$ & 5 & 2,8 & 22 & 46 & 18 & 14 & \\
\hline B12- Uzaktan psikolojik danışma hizmetleri. & 21 & 2,6 & 28 & 24 & 30 & 18 & \\
\hline $\begin{array}{l}\text { B13- Psikolojik Danışmanlık ve Rehberlik lisans } \\
\text { programlarından mezunlarının özel üniversitelerde } \\
\text { klinik psikoloji yüksek lisans programını bitirdikten } \\
\text { sonra ''Klinik Psikolog' unvanını kullanmaları. }\end{array}$ & 6 & 2,5 & 20 & 36 & 14 & 30 & \\
\hline $\begin{array}{l}\text { B14- Psikolojik danışmanların danışanları ile kurdukları } \\
\text { cinsel ikili ilişkiler. }\end{array}$ & 0 & - & - & - & - & - & \\
\hline $\begin{array}{l}\text { B15- Psikolojik danışmanların gizlilik ilkesini bildiği } \\
\text { halde başka bir nedenden dolayı (kişisel çıkar, ihmal, } \\
\text { dikkat eksikliği) gizlilik ilkesini ihmal etmeleri. }\end{array}$ & 0 & - & - & - & - & - & \\
\hline $\begin{array}{l}\text { B16- Psikolojik danışmanların danışanları ile kurdukları } \\
\text { cinsel olmayan ikili ilişkiler. }\end{array}$ & 0 & - & - & - & - & - & \\
\hline $\begin{array}{l}\text { B17- Psikolojik danışmanların gizlilik ilkesini } \\
\text { bilmemeleri. }\end{array}$ & 0 & - & - & - & - & - & \\
\hline
\end{tabular}

Açıklama: Açıklama: * 2. turda katılımcılar tarafından toplam işaretlenme sayısı, ** 3. turda katılımcıların cevaplarının Likert ölçeğine göre (1. Derecenden önemli 4 puan, 4 . Derecede önemli 1 puan) aritmetik ortalaması, $* * * 3$. turda katılımcıların cevaplarının önem derecesine göre yüzdeleri. $* * * *$ 3. tur sonuçlarına göre (aritmetik ortalama) ilk 5 'te yer alan temaların sıralaması. 


\section{Tartışma}

Bu çalışmada elde edilen bulgular ışığında, tartışma altı başlık altında toplanmıştır. Bu başlıklar, psikolojik danışmanların günümüzde ve gelecekteki potansiyel etik problemler hakkında görüşlerini içeren sonuçların literatür ile birlikte tartışılmasını kapsamaktadır.

\section{Psikolojik danışmanların etiğin tanımı ve ilkeleri hakkındaki genel bilgi seviyesi}

Çalışma sonucunda psikolojik danışmanlardan gelen veriler analiz edildiğinde, verilen cevapların tam olarak etik kodları yansıtmak yerine daha çok cümleler haline psikolojik danışmanlık ve rehberlik alanında yaşanan problemleri yansıttığı görülmüştür. Türk PDR Derneği'nin (2006) etik kodları sekiz genel kategoride (genel standartlar, danışmanlık ilkeleri, değerlendirme, araştırma ve yayın, danışma, danışmanlık eğitimi, özel uygulama ve personel yönetimi) listelenen 101 madde içermektedir. Ancak çalışma sonucunda psikolojik danışmanların yetkinliği, gizlilik ilkesinin bilinmemesi, farklı alanlardan mezun olan kişilerin psikolojik danışmanไrehber öğretmen olarak çalışması gibi, sadece birbirini tekrarlayan belli başlı kodlar dikkat çekmektedir. Ayrıca bazı psikolojik danışmanların branşlaşamama ve unvan problemlerini etik sorun olarak görmeleri de önemlidir. Bu hususlar etik sorunlara yol açan uygulamalara sebep olabilir, ancak etik sorundan daha çok yasal problem olarak değerlendirilmelidir. Psikolojik danışmanların psikolojik danışma seanslarında karşılaştıkları belirgin etik problemler hakkındaki görüşlerinden ziyade, daha geniş çerçevede ve kuramsal sonuçlar bu çalışmada ortaya çıkmıştır.

$\mathrm{Bu}$ sonuçlara göre psikolojik danışmanların lisans düzeylerinde aldıkları etik dersinin kapsamında bazı sınırlılıklar olduğu göze çarpmaktadır. Hardal (2011) çalışmasında bu konuya dikkat çekmiş ve lisans düzeyinde verilen az sayıda dersin eksikliğini vurgulamıştır. Yine literatürde İkiz ve diğerlerinin (2017b) çalışmasında da lisans düzeyindeki etik dersinin sınırlılığ vurgulanmış ve üniversitelerde verilen meslek etiği derslerinin güncel yasa ve çalışma koşulları ile uyumlu olması önerilmiştir. Verilerin analizi ve literatür taraması ile uyumlu olarak lisans düzeyinde verilen etik dersinin ve eğitiminin, değişen dünyanın değişen ihtiyaçları ile uyumlu olması ve alanda çalışan psikolojik danışmanların farklı sorunlarla karşılaştıklarında etik olarak doğru kararlar vermeleri adına, lisans düzeyindeki etik dersinin kapsamının ve süresinin arttırılması önerilebilir. Bunun yanında etik konusunda psikolojik danışmaların sadece lisans düzeyinde aldıkları etik dersi ile yetinmeyip, hizmet içi eğitimler ve diğer uygulamalar ile devamlılı̆̆ın sağlanmasının, psikolojik danışmanların "etik nedir" sorusuyla ilgili bilgi sahibi olmaları adına önemli olduğu düşünülmektedir.

\section{Gizlilik}

Gizlilik, psikolojik danışma sürecinde güvene dayalı bir ilişki gelişmesi açısından çok önemli konulardan biridir. Süreç içerisinde psikolojik danışman gizliliğe bağlı kalacağını vaat ederek, danışan açısından güven ortamını sağlamakla yükümlüdür. Ancak gizlilik bazı durumlarda psikolojik danışmanın temel ilkeleri ile çelişebileceği için katı bir şekilde sürdürülebilecek bir ilke değildir (Camadan, 2018). Psikolojik danışman gerekli gördüğü durumlarda (danışanın kendisine ya da bir başkasına zarar vermesi, bunu planladığını anlatması vb.) gizlilik ilkesini bozarak durumu yetkili kişi ve kurumlara bildirmekle yükümlüdür. Bu psikolojik danışmanın topluma karşı bir sorumluluğudur. Gizliliğin bozulmasını gerektiren durumlarda psikolojik danışmanlar etik ikilemler yaşarlar. Literatüre bakıldığında danışmanların gizlilik konusunda etik ikilem ve etik ihlal yaşadıkları göze çarpmaktadır (Akfert, 2012; Çetinkaya, 2014; 2015; Herlihy ve Dufrene, 2011; İkiz ve diğerleri, 2017a; Lehr ve diğerleri, 2007; Yam, 2017). Çalışmanın sonuçlarına bakıldığında psikolojik danışmanların günümüzdeki sorun temaları arasında, ilk sırada psikolojik danışmaların gizlilik ilkesini bilmemelerinden kaynaklanan etik sorunlardan bahsettikleri görülmektedir. Bu sonuç yine lisans düzeyindeki etik dersinin sınırlılığını akla getirmektedir (İkiz ve diğerleri, 2017c). Gizlilik gibi önemli bir konuda psikolojik danışmanların yeterince bilgi sahibi olmaması, verilen ruh sağlı̆̆ hizmetini olumsuz etkileyebilir. Bu anlamda lisans düzeyinde verilen etik dersinin kapsamı ve süresi genişletilebilir. Bu şekilde psikolojik danışman adaylarının mezun olduklarında yaşadıkları ikilemlerde etik açıdan daha uygun kararlar almaları sağlanabilir. Psikolojik danışmanlara sağlanacak hizmet içi eğitimlerle de etik açıdan 
yaşanan sorunların çözümüne ilişkin psikolojik danışmanların daha hazır olmaları sağlanabilir. Ayrıca nitelikli bir ruh sağlığı hizmeti sunmak ve danışanlara zarar vermeyi de kapsayan yanlış uygulamaları önlemek amacıyla, alan çalışanlarını denetleme mekanizmalarının oluşturulması zorunlu gibi görünmektedir (Taşdan ve Yalçın, 2007). Bu kapsamda psikolojik danışmanlara süpervizyon desteği için Milli Eğitim Bakanlığının bir çalışma başlatmasının gerekli olduğu düşünülmektedir.

Çalışma sonuçlarına bakıldığında psikolojik danışmanların gelecekteki etik sorun temaları arasında gizlilik ile ilgili problemleri 15. sırada ele almaları göze çarpan bir başka noktadır. Psikolojik danışmanlar günümüzdeki sorun temaları arasında gizliliği ilk sırada ele alırken, bu hususu gelecekte yaşanabilecek sorun temaları arasında 15. sırada göstermeleri önemlidir. Bu çalışmaya katılan psikolojik danışmanlar, gizlilik konusunun gelecekte, günümüze oranla daha az önemli bir etik problem olarak karşımıza çıkacağını düşünmektedirler.

\section{Yetkinlik}

Psikolojik danışma hizmeti profesyonel bir hizmettir ve psikolojik danışman bu hizmeti verirken en üst düzeyde yeterlilikle yürütmeyi amaçlar. Psikolojik danışman aldığı eğitimler kapsamında uzmanlık alanlarını ve yetkinliğinin sınırlarını bilir (TPDRD, 2012). Psikolojik danışmanların mesleki olarak kendilerini yetkin olarak görmeleri, verecekleri yardım hizmetinin etkili olabilmesi için önemlidir (Gündüz ve Çelikkaleli, 2009). Verilen profesyonel hizmet kapsamında psikolojik danışmanın yetkinliğinin dışına çıkması, danışana zarar verebilme potansiyeli olan etik bir ihlaldir. Literatürde yetkinlik önemli bir tartışma konusu olarak karşımıza çıkmaktadır.

\section{Alan dışı atamalar}

Koçak ve Kavak'a (2014) göre “öğretmen ihtiyacının karşılanamadığı durumlarda gerçekleştirilen alan dışı atamalarda, ihtiyacın karşılanması durumunda, alan dışı atanmış ögretmenlerin kendi alanlarına veya yakın alana geçişlerine olanak tanıyan düzenleme ve uygulamalar yapılmıştır. Bu uygulamalar, bazen öğretmenlerin istekleri, bazen de MEB'in istekleri doğrultusunda gerçekleşmiştir" (s. 166). Bu uygulama okullarda rehber öğretmen kadrolarına psikolojik danışmanlar yerine felsefe, sosyoloji gibi bölümlerden mezun kişilerin atanmalarına yol açmıştır. Lisans eğitimi psikolojik danışmanlık ve rehberlik alanından olmayan kişilerin bu alanda çalışması, yetkinlik açısından endişe verici bir durumdur. Yapılan çalışmalarda yetkin olmayan kişilerin okul psikolojik danışmanı olarak çalışmaları önemli bir etik sorun olarak görülmektedir (Akfert, 2012; Camadan, 2018; Hardel, 2011; İkiz ve diğerleri, 2017b; Lehr ve diğerleri, 2007). Çalışma sonuçları incelendiğinde psikolojik danışmanların günümüzde sorun olabilecek temalar konusunda 3. sırada alan dışı kişilerin pedagojik formasyon alıp çalışmalarını, gelecekte sorun olabilecek temalar konusunda da aynı sorunu 2. sirada gördükleri belirlenmiştir. Psikolojik danışmanların verdikleri bu yanıtlar literatür sonuçları ile uyumlu gözükmektedir (İkiz ve diğerleri, 2017c). Psikolojik danışma hizmetinin profesyonel bir hizmet olduğu göz önünde bulundurulduğunda, bu hizmeti verecek kişilerin uygun eğitimi almamasının hem toplum hem de yardım alan birey açısından kaygı verici olacağı düşünülebilir.

\section{Psikoterapist unvanı}

Psikoterapist unvanı üniversite eğitimi ile alınan bir unvan olmayıp, herhangi bir yaklaşımın uygulama eğitimini veren özel enstitülerin koşullarını yerine getirenlerin sahip olabildikleri bir unvandır (Akkoyun,1995). Ülkemizde mevcut bir ruh sağlığı yasasının olmaması psikolojik danışman, psikolog, psikoterapist gibi unvanların birbirine karışmasına yol açmaktadır. Çalışma sonuçlarına göre psikolojik danışmanlar günümüzdeki ve gelecekteki sorun temaları arasında, herhangi bir kurumdan alınan kısa süreli eğitim ile verilen sertifika kapsamında psikoterapist unvanının kullanılmasını etik bir sorun olarak görmektedirler. Ruh sağlığı hizmetinin profesyonel bir hizmet olması, bu hizmeti verecek kişilerin profesyonel olmasını gerektirmektedir. Kısa süreli eğitimler ile alınan sertifikalarla psikoterapist unvanının kullanılması etik olarak uygun olmadığı gibi, bu unvana göre bilindiği varsayılan yaklaşımın aslında bilinmemesi danışana zarar verme durumunu düşündürmektedir. Bugün pek çok kişi ve kurum maddi kaygılardan dolayı bu kısa 
süreli eğitimleri tercih etmektedirler. Bu durum profesyonel olması gereken psikolojik danışma hizmeti hakkında soru işaretleri oluşturmaktadır.

\section{Unvan problemi ve meslek yasasının önemi}

Psikolojik danışma ve rehberlik alanı ülkemizde yaklaşık 60 yıllık bir geçmişe sahiptir. Bu açıdan bakıldığında Türk Milli Eğitim Sistemi içerisinde psikolojik danışma ve rehberlik çalışmalarının uzun bir geçmişi olduğu söylenebilir (Arslan ve Sommers-Flanagan, 2018b; Doğan, 1996). Psikolojik danışma ve rehberlik alanı ülkemizde uzun bir geçmişe sahip olmasına rağmen bu alandan mezun olan kişilerin unvan sorunu günümüzde halen devam etmektedir. Yaşanan bu unvan sorunu alan çalışanları açısından olumsuz bir durum yaratırken, psikolojik danışma ve rehberlik alanı açısından da kafa karıştırıcı bir izlenim vermektedir. Unvan sorunu bağlamında görev tanımı ve yeterlilikleri değişmektedir. Sürekli hale gelen değişim ise alan için yıpratıcı olmaktadır. Çalışma sonuçlarına bakıldığında psikolojik danışmanların günümüzde sorun olabilecek temalarda 7. sırada "psikolojik danışmanların mesleki çerçeve ve unvanları ile ilgili sorunlarının uygulamada yarattığı etik problemler" temasını görmeleri ve gelecekte sorun olabilecek temalar arasında da 8. ve 13. sırada unvanlarla ilgili temaları seçmeleri önemlidir. Psikolojik danışmanlık ve rehberlik alanında yaşanan unvan sorunu, bazı yerlerde alandan olmayan ve etik kaygi gütmeyen kişilerin, profesyonel olarak yürütülmesi gereken bu hizmeti etik ve yasal olarak sorunlu bir uygulama haline getirmelerine sebep olmuştur. Bu durum hem bu tür kişilerden yardım almak isteyen bireylerin ruh sağlığını olumsuz etkileyebilir, hem de ülkemizde ruh sağlı̆̆ hizmeti için yine olumsuz bir alg1 uyandırabilir. Tüm bunlar çerçevesinde 60 yıldan uzun süredir Türk Milli Eğitim Sistemi'nde yer alan psikolojik danışma ve rehberlik alanı için, bu unvan sorununun yetkili kişi ve kurumlar tarafından ele alması önerilebilir.

\section{Türk PDR etik kodlarının yenilenmesi}

Çalışmanın sonuçlarına göre, bilgi kirliliğinden kaynaklanan etik kod karmaşası gelecekte yaşanabilecek etik problemler arasında 5. sıradır. Türk PDR Derneği en son 2006 yılında etik kodları revize etmiştir ve bu etik kodlar günümüzde yaşanan etik problemler ile ilgili takip edilebilecek tek psikolojik danışmanlık etik kodlarıdır. Günümüzde ve gelecekte psikolojik danışmanlık mesleğinin etik problemlerine yönelik olarak Türk PDR Derneği'nin etik kodlarının revize edilmesi önemlidir. Ayrıca etik alanındaki bilimsel kaynakların (Türk PDR Derneği Etik Kodları, bilimsel kitaplar ve makaleler) psikolojik danışmanlara ulaştırılması yönünde çalışmalar yapılması önerilir.

\section{Çok kültürlü psikolojik danışma}

Psikolojik danışma sürecinde psikolojik danışmanın farklı müdahale stratejileri geliştirmesi adına danışan farklılıklarına duyarlı olmaları oldukça önemlidir (Corey, 2015) Hem psikolojik danışmanın hem de danışanın kültürel değişkenleri sürecin çok önemli özellikleridir (Kağnıcı, 2013). Değişen dünyada yaşanan gelişmeler sonucunda sosyal alandaki değişimlerin ülkemizi kolektif bir toplum yapısından bireyselci bir toplum yapısına yaklaştıracağı düşünülebilir. $\mathrm{Bu}$ açıdan bakıldığında da çok kültürlü psikolojik danışma anlayışı değişen parametreler bağlamında ülkemiz için bir zorunluluk olarak görülmektedir (Karaırmak, 2008). Psikolojik danışma süreci açısından düşünüldüğünde de danışan farklılıklarına saygı duymayan veya bu farklılıkların bilincinde olmayan bir psikolojik danışmanın hem danışana zarar verebileceği, hem de sürecin doğasına aykırı hareket edeceği düşünülebilir. Literatür çalışmalarına bakıldığında Arslan ve Sommers-Flanagan'ın (2018) çalışmasında psikolojik danışman adaylarının bazılarının homoseksüelliği patolojik bir rahatsızlık olarak gördükleri sonucuna ulaşılmıştır. Bu sonuç psikolojik danışmanlığın temel değerleri düşünüldüğünde oldukça problemlidir.

Çalışmanın sonuçlarına bakıldığında psikolojik danışmanların günümüzdeki sorun temaları arasında 5. sırada "psikolojik danışmanların ön yargılarından dolayı farklılıklara saygı duymaması" temasını seçtikleri ve gelecekte yaşanabilecek sorun temaları arasında ise aynı temayı 3. sıraya almaları önemlidir. Sonuçlar açısından düşünüldügünde psikolojik danışman eğitimine çok kültürlü psikolojik danışma konularının entegre edilmesinin ne kadar önemli 
olduğu bir kez daha anlaşılmaktadır. Sınırların değişmesi, göç, mültecilik gibi olaylar ülkelerin nüfus yapılarını değiştirmiştir. Türkiye de bu süreçte hızla göç alan ülkeler arasında yer almaktadır. Hem göç ile gelen nüfusun farklı kültürel değerlere sahip olması, hem de hâlihazırda ülkemizde yaşayan insanların çok farklı kültüre sahip olması bir zenginliktir. Kültürel değerlerin bu derece zengin olduğu ülkelerde çok kültürlü psikolojik danışma konusu da giderek önem kazanmaktadır. Ülkemizin de böyle bir yapısı olduğu düşünüldüğünde ruh sağlığı veren kişilerin bu durumun farkında olarak eğitim almalarının önemli olduğu söylenebilir. Bu bağlamda lisans derslerine çok kültürlü psikolojik danışma ile ilgili derslerin eklenmesi ve hizmet içi eğitimlerle çok kültürlü psikolojik danışma yetkinliklerinin devamlılığının sağlanması önerilebilir.

\section{Uzaktan psikolojik danışma}

Uzaktan psikolojik danışma, internetin kolay ulaşılabilir bir duruma gelmesi ve yeni nesil akıllı telefonların yaygınlaşması ve diğer mobil iletişim imkânlarının artması ile oldukça önem kazanmış yeni bir yardım biçimidir. Özellikle yüz yüze herhangi bir psikolojik danışmana ulaşma imkânı olmayan kişiler için alternatif bir yol sunmaktadır. Aynı zamanda damgalanma korkusu yaşayanlar ve yüz yüze psikolojik danışma sürecinde kendini açmada sorun yaşayan kişiler için farklı bir seçenek oluşturmaktadır (Zeren, 2015). Literatüre bakıldığında 14 farklı çalışmadaki 9.764 danışan ile yapılan bir çalışmada uzaktan psikolojik danışmanın yüz yüze psikolojik danışma kadar etkili olduğu sonucuna ulaşılmıştır (Barak, Hen, Boniel-Nissim ve Shapira, 2008). Özellikle ülkemizde uzaktan psikolojik danışmanın oldukça yeni bir konu olması uygulamada etik sorunların yaşanabileceği endişesini de beraberinde getirmektedir. Bu açıdan bakıldığında konu ile ilgili etik kodların oluşturulması son derece önem taşımaktadır (Zeren ve Bulut, 2018). Ayrıca uzaktan psikolojik danışmada, psikolojik danışman ve danışan açısından gizliliğin sağlanması, etik kuralların ve diğer uzaktan psikolojik danışma konularının alanda çalışanlarca işbirliği içinde oluşturulması gerekmektedir (Bozkurt, 2013).

Çalışmanın sonuçlarına bakıldığında psikolojik danışmanların günümüzdeki sorun temaları arasında 14 tema içerisinde "uzaktan psikolojik danışma" temasını belirtmedikleri görülmektedir. $\mathrm{Bu}$, uzaktan psikolojik danışmanlığın günümüzde henüz çok fazla yaygınlaşmamasına bağlı olarak beklendik bir sonuç olarak düşünülebilir. Çalışmaya katılan psikolojik danışmanların gelecekte sorun olabilecek temalar arasında ise 12. sırada "uzaktan psikolojik danışma" temasını belirtmeleri bu alternatif yardım hizmetinin giderek yaygınlaşıp alana dâhil olacağı ve yeni bir etik teması yaratacağı izlenimi vermektedir. Halihazırda alanda çalışan psikolojik danışmanların, başta gizlilik olmak üzere diğer etik konularda yeterli eğitim almamaları ve etik dersinin lisans düzeyinde sadece iki kredilik tek bir ders olması, uzaktan psikolojik danışma gibi etik ve etkililik açısından tartışmalı bir konunda endişe oluşturabilecek unsurlar olarak düşünülebilir. Psikolojik danışmanların değişen toplum ihtiyaçlarına duyarlı olmaları düşünüldüğünde, yaygınlaşan uzaktan psikolojik danışma hizmeti konusunda etik olarak bilinçli ve yetkinliklerinin farkında olmaları, danışanın ruh sağlığı açısından oldukça önemlidir. Literatürle uyumlu olarak yeni ve alternatif bir yardım hizmeti olan uzaktan psikolojik danışmanlık konusunda lisans düzeyinde verilen etik eğitiminin yanı sıra, hizmet içi eğitimler ve farklı bilgilendirme sistemleri ile psikolojik danışmanların bu konu hakkında bilgi sahibi olmaları önerilebilir. Bu hususta internet güvenliğinin tartışıldığı günümüzde hem psikolojik danışmanı hem de danışanı korumak adına teknolojik yardım hizmetlerinin bu eğitim ve bilgilendirmeye eklenmesi başka bir öneri olarak sunulabilir.

\section{Çalışmanın alana katkıları}

$\mathrm{Bu}$ çalışma alanda belli bir süre çalışan psikolojik danışmanların karşılaştıkları etik sorunları ve gelecekteki olası etik sorunlar hakkındaki düşüncelerine ilişkin fikirlerini bize sunmaktadır. Bu çalışmanın sonuçlarının alana katkılarını şöyle özetleyebiliriz:

(a) Türk psikolojik danışmanlık alanında uzun süredir revize edilmeyen etik kodların revize edilmesi halinde, hangi yeni etik durumlarının göz önüne alınması gerektiğine dair fikirler vermektedir. 
(b) Psikolojik danışmanlık lisans programlarındaki etik dersinin içeriğinin zenginleştirilmesi, kredi sayısının arttırılması ve diğer dersler işlenirken etik konularının bu derslere entegre (infused) edilmesi konusundaki önemi göstermiştir.

(c) Psikolojik danışmada gizlilik konusunun hala Türkiye'deki en önemli etik problemlerden birisi olmaya devam ettiğini göstermiştir.

(d) Yetkinlik konusunda hem psikolojik danışman olmayanların psikolojik danışman olarak görev yapması, hem de psikolojik danışmanların başka unvanları kısa süreli programlara katılarak kullanmaları etik problemler arasında görülmüştür.

(e) Türkiye'de ruh sağlığı meslek yasasının olmayışının, psikolojik danışmanlar tarafından etik ihlallere sebep olabileceği belirtilmiştir.

(f) Psikolojik danışmanların çok kültürlü psikolojik danışma yetkinliklerinin yeterli olmamasının, hem günümüzde hem de gelecekte etik ihlallere sebebiyet verebileceğini göstermiştir. Psikolojik danışmanlık programlarında çok kültürlü psikolojik danışma dersinin olmasının önemini bir kez daha ortaya çıkarmıştır.

(g) Son olarak, uzaktan psikolojik danışmanlığın yaygınlaşma ihtimaline ilişkin, psikolojik danışmanların bu konuda etik kurallara sahip olma ihtiyaçlarını ortaya çıkarmıştır.

\section{Kaynaklar}

Akfert, S. K. (2012). Farklı kurumlarda çalışan psikolojik danışmanların yaşadıkları etik ikilemler ile bu ikilemler karşısındaki tutum ve davranışları. Kuram ve Uygulamada Eğitim Bilimleri, 12(3), 1791-1812.

Akkoyun, F. (1995). PDR'de unvan ve program sorunu: bir inceleme ve öneriler. Türk Psikolojik Danışma ve Rehberlik Dergisi, 2(6), 1-21.

American Counseling Association. (2014). Code of ethics. Alexandria: ACA.

American School Counselor Association. (2010). Ethical standards for school counselors. Alexandra, VA: Author.

Arslan, Ü. ve Sommers-Flanagan, J. (2018a). Ethical beliefs of counseling students in Turkey. Pamukkale Üniversitesi Eğitim Fakültesi Dergisi [PAU Journal of Education] 44,196212. doi: 10.9779/PUJE.2018.214

Arslan, Ü. ve Sommers-Flanagan, J. (2018b). The new stage of the Turkish counseling system: explosive growth (2000 to the present). Journal of Multicultural Counseling and Development, 46, 115-128. doi:10.1002/jmcd.12096

Barak, A., Hen, L., Boniel-Nissim, M. ve Shapira, N. A. (2008). A comprehensive review and a meta-analysis of the effectiveness of internet-based psychotherapeutic interventions. Journal of Technology in Human Services, 26(2-4), 109-160.

British Association for Counselling and Psychotherapy. (2018). Ethical framework for the counselling professions. Lutterworth, Leicestershire, UK.

Bozkurt, İ. (2013). Psikolojik yardım uygulamalarında yeni trend: online terapiler. International Journal of Human Sciences, 10(2), 130-147.

Camadan, F. (2018). Psikolojik danışmanın yaşadığı çatışma: etik ikilem. Sakarya Üniversitesi Eğitim Fakültesi Dergisi, 8(1),76-94.

Corey, G. (2015). Psikolojik danı̧̧ma, psikoterapi kuram ve uygulamaları. T. Ergene (Çev.) Ankara: Mentis.

Çetinkaya, R. S. (2015). Ethical dilemmas of Turkish counsellors: a critical incidents study. British Journal of Guidance \& Counselling, 43(4), 476-491, doi: 10.1080/03069885. 2014.987726

Çetinkaya, R. S. (2014). Ethical judgments of counselors: results from a Turkish sample. Ethics \& Behavior, 25:5, 400-417, doi: 10.1080/10508422.2014.941981

Doğan, S. (1996). Türkiye'de Psikolojik danışma ve rehberlik alanında meslek kimliğinin gelişimi ve bazı sorunlar. Türk Psikolojik Danışma ve Rehberlik Dergisi, 2(7), 32-44.

Ergene, T. (2004). Psikolojik danışmada etik ikilemler: etik karar verme süreci. Eurasian Journal of Educational Research, 15, 49-55. 
Gündüz, B. ve Çelikkaleli, Ö. (2009). Okul psikolojik danışmanlarında mesleki yetkinlik inancı. Mersin Üniversitesi Ĕgitim Fakültesi Dergisi, 5(1), 119-133.

Hardal, M. (2011). Common ethical violations and ethical action patterns among Turkish mental health professionals and the factors that influence them (Yayımlanmamış yüksek lisans tezi). İstanbul Bilgi Üniversitesi Sosyal Bilimler Enstitüsü, İstanbul.

Herlihy, B. ve Dufrene, R. L. (2011). Current and emerging ethical issues in counseling: a delphi study of expert opinions. Counseling and Values, 56, 10-24.

İkiz, F. E., Otlu, B. M. ve Arslan, Ü. (2017a). Trainee psychological counselors' understanding of ethics. International Journal of Humanities and Social Science Invention, 6(2), 20-17.

İkiz, F. E., Sevinç, A., Kaval, A., Yeğintürk, G. ve Kalen, S. (2017b). Okul psikolojik danışma hizmetlerinde mesleki etik ihtiyaçlarının belirlenmesi. İş Ahlakı Dergisi, 10(2), 223-245.

İkiz, F. E., Şensoy, G., Balkan, K. ve Akıman, H. (2017c). Psikolojik danışmanların meslek etiğine yönelik algıları: özel çalışanlara yönelik bir inceleme. Insan ve Toplum Bilimleri Araştırmaları Dergisi, 6(4),152-171.

Jones, R. N. (2013). Temel psikolojik danışma becerileri. G. Sart (Çev.) Ankara: Nobel.

Jones, R. N. (2014). Uygulamalı danışmanlık ve yardım becerileri. (Çev. G. Sart) Ankara: Nobel.

Kağnıcı, D.Y. (2013). Çok kültürlü psikolojik danışma eğitiminin rehberlik ve psikolojik danışmanlık lisans programlarına yerleştirilmesi. Türk Psikolojik Danışma ve Rehberlik Dergisi, 5(40), 222-231.

Karaırmak, Ö. (2008). Çok kültürlülük, kültürel duyarlılık ve psikolojik danışma. Türk Psikolojik Danışma ve Rehberlik Dergisi, 3(29), 115-129.

Koçak, S. ve Kavak, Y. (2014). Milli Eğitim Bakanlığı'nın öğretmen atama esasları ve kaynak yükseköğretim programlarıyla ilgili gelişmeler. Hacettepe Üniversitesi Eğitim Fakültesi Dergisi. 29(4), 157-170.

Lehr, R., Lehr, A. ve Sumarah, J. (2007). Confidentiality and informed consent: school counsellors' perceptions of ethical practices. Canadian Journal of Counseling, 4l(1), 1630.

Oktay, B. ve Oktay, Y.F. (2018). Bir etik ihlal olarak hasta ve terapist arasındaki cinsel ilişkiler. Süleyman Demirel Üniversitesi Fen-Edebiyat Fakültesi Sosyal Bilimler Dergisi, 44, 103110.

Rowe, G. ve Wright, G. (1999). The Delphi technique as a forecasting tool: issues and analysis. International journal of forecasting, 15(4), 353-375. doi: 10.1016/S01692070(99)00018-7

Skulmoski, G. J., Hartman, F. T. ve Krahn, J. (2007). The delphi method for graduate research. Journal of Information Technology Education, 6(1), 1-21.

Taşdan, M. ve Yalçın, İ. (2007). Psikolojik danışma ve rehberlikte etik. Mehmet Akif Ersoy Üniversitesi Ë̆iti Fakültesi Dergisi, 14, 99-107.

Türk Psikolojik Danışma ve Rehberlik Derneği (2012). Psikolojik danışmanlık ve rehberlik alanında çalı̧̧anlar için etik kodlar. (8. b.s.), Ankara: Türk Pdr Derneği Yayınları.

Yam, F. C. (2017). Psikolojik danışmanların yaşamış oldukları etik ikilemler ve bu etik ikilemler karşısındaki duygu, düşünce ve davranışları ile çözüm engelleri: nitel bir değerlendirme. Uluslararast Sosyal Araştırmalar Dergisi, 10(48), 465-477.

Zeren, Ş. G. (2015). Yüz yüze ve çevrimiçi psikolojik danışma: danışanların sorunları ve memnuniyetleri. Eğitim ve Bilim, 40(182), 127-141.

Zeren, Ş. G. ve Bulut, E. (2018). Çevrimiçi psikolojik danışmada etik ve standartlar: Bir model önerisi. Türk Psikolojik Danışma ve Rehberlik Dergisi, 8(49), 63-80.

\section{Extended Abstract}

\section{Introduction}

Ethics is related to the morality concept which includes the correct and incorrect distinction in human behavior, the accepted rules, and standards of human behavior. In the field of psychological counseling, ethics implies internationally recognized standards for professional 
practice (Jones, 2014). Ethical codes are created to protect these standards. Ethical codes for Turkish psychological counselors were first introduced by Turkish Psychological Counseling and Guidance Association (1995) 6 years after its establishment, and the revised version of the code (2006) is still in use. In Turkey, compared to other studies in psychological counseling, studies on ethics are limited. Studies related to ethics in Turkey mainly focus is on confidentiality, dual relations, and competency. There are two main objectives of this study, which are trying to identify the current ethical problems experienced by psychological counselors and to determine the predictions of future ethical problems from the perspective of psychological counselors.

\section{Method}

Skulmoski et al. (2007) stated that the Delphi method consists of 11 stages. The procedure of this study was based on the Skulmoski and colleagues' approach.

\section{Developing the research question}

The first stage of this study is to recognize the need for research in determining the current and future ethical problems in counseling. The research questions of the article are influenced by Herlihy and Dufrene (2011), who discuss the current and future ethical problems with American psychological counseling experts. Therefore, "What is most important (current and prospective) ethical problems for counselors in Turkey?" question is designated as a research question of this study.

\section{Design of research}

This research was conducted by a Delphi method. The Delphi method is a process that collects and evaluates the opinions of experts through repetitive feedback with an ordered questionnaire (Skulmoski et al., 2007).

\section{Sample of research}

In Delphi studies, the participant group must have a certain degree of knowledge about the study. The aim of this study is to observe the ethical problems that exist in the field of psychological counseling and to observe the probable ethical problems in the coming years. Therefore, the participants of the study were identified as psychological counselors with at least five years of experience in the Turkish psychological counseling field. The questionnaire was applied to the participants via the Google form so that the confidentiality and volunteering of the participants were ensured and there were no delays due to the traditional communication methods. Announcements were made to psychological counseling and guidance pages on social media. The links of the questionnaires were sent to the volunteer participants via e-mail. 52 participants were completed three steps in the study.

\section{Developing the first questionnaire for a delphi study}

At this stage, it was tried to be organized as a survey which participants can freely answer. In this context, two open-ended questions were asked for participants to write their own ideas for current and future ethical problems.

\section{Delphi pilot study}

The questions were discussed before finalizing with the graduate students and counselor educators. The latest version of the questions are:

- In your opinion, what are the most important ethical problems in counseling field currently? Write at least three problems.

- In the next five years, what ethical problems do you think will arise in counseling? Write at least three problems. 
Collecting and explaining the results of the first round of the survey

The results of the first round are categorized. This categorization is done by coding the given answers. The results of the first round consisted of 14 categories for the current ethical problem and 17 categories for future ethical problems.

\section{Development of the survey for the second round}

In the second round, categories, which were created after the first round, were asked to participants to select the most important ones by asking the following questions.

- In your opinion, what are the most important ethical issues in counseling currently? Mark the three options.

- In the next five years, what ethical problems do you think will arise in counseling? Mark the three options.

\section{Collecting and explaining the results of the second round of the survey}

In the second round, the most and least preferred categories were determined according to the answers of the participants.

\section{Developing the survey for the third round}

The questionnaire was developed to raise the questions of the most preferred questions and to ask the participants to exclude the least preferred questionnaire questions. In this context, 14 categories related to current ethical problems and 17 categories related to the future ethical problems were asked to be ranked by Likert (One to Four) type questionnaire.

- Please mark the importance level of these ethical problems in counseling field currently according to your experience.

- In the next five years, please indicate the importance level of these future ethical problems in the counseling field, according to your experience.

Collecting and explaining the results of the third round of the survey

Arithmetic averages of the answers given in the questionnaires were calculated and analyzed.

Verification, generalization and reporting of research results

The results of the research analyzed with the literature and reported.

\section{Results}

In total, 52 participants' answers received and analyzed in three rounds. All participants have been working as psychological counselors for at least five years. 32 participants were male, and 20 participants were female.

\section{Current ethical issues}

Three rounds of the survey were conducted to determine the ethical problems that psychological counselors face currently.

a) In the first round, open-ended questions asked and 14 categories were created as a result of the responses.

b) In the second round, participants were asked to select the three most important ethical problems from the categories formed based on the first round. The participants marked 11 out of 14 categories at least once and remaining three categories were never marked. Giving permission to non-counselors to work as counselors, title problems related to short-term training, multicultural counseling and competency were the most marked categories compared to other categories. 
c) In the third round, Likert-type questionnaire was used to indicate the importance of current ethical problems (1st, 2nd, 3rd, and 4th), and their arithmetic averages were calculated. The first five items with the highest average are confidentiality, giving permission to non-counselors to work as counselors, competency and multicultural counseling.

\section{Future ethical issues}

Three rounds of surveys were conducted to determine the ethical problems that psychological counselors might face in the future.

a) In the first round, open-ended questions asked and 17 categories were created as a result of the responses.

b) In the second round, participants were asked to select the three most important ethical problems from the categories formed based on the first round. The participants selected 13 out of 17 categories at least once and remaining three categories were never selected. title problems related to short-term training, giving permission to non-counselors to work as counselors and multicultural counseling were the most marked categories compared to other categories.

c) In the third round, Likert-type questionnaire was used to indicate the importance of current ethical problems (1st, 2nd, 3rd, and 4th), and their arithmetic averages were calculated. The first five items with the highest average are competency, Giving permission to non-counselors to work as counselors, confidentiality, multicultural counseling, the lack of the branch of the psychological counseling profession, and confusion of ethical codes.

\section{Discussion}

This study presents psychological counselors' opinions about ethical problems, who work in the field for a certain period of time. The contributions of the results of this study to the field can be summarized as follows:

(a) Ideas about new ethical situations should be added into consideration in revising the ethical codes that have not been revised for a long time in the Turkish psychological counseling field.

(b) Importance of to enrich the content of the ethics course in the psychological counseling undergraduate programs, to increase the number of credits and to integrate the ethical issues into these courses.

(c) Confidentiality in counseling still continues to be one of the most important ethical problems in Turkey.

(d) Two important competence problems are non-counselors working as psychological counselors, and psychological counselors use other titles by participating in short-term programs.

(e) The lack of mental health profession laws in Turkey could lead to ethical violations,

(f) The lack of adequate multicultural counseling competencies has shown that it may lead to ethical violations both today and in the future. The importance of having multicultural counseling courses in psychological counseling programs once again revealed.

(g) Finally, in the face of the possibility of the extension of online counseling, the need for psychological counselors to have ethical rules was revealed. 